\title{
TOCQUEVILLE, O ASSOCIATIVISMO E ALGUNS APONTAMENTOS SOBRE O TERCEIRO SETOR
}

\author{
Tocqueville, the associativism and some \\ points about the third sector
}

\section{Luís Antonio Groppo}

Doutor em Ciências Sociais pela UNICAMP. Professor do Programa de Mestrado em Educação do Unisal, Americana-SP. Pesquisador do CNPq, Campinas, SP - Brasil, e-mail: luis.groppo@am.unisal.br

\begin{abstract}
Resumo
Baseado na análise da principal obra de Alexis de Tocqueville, "A democracia na América", dos anos 1830, demonstra-se a importância das associações livres no projeto liberal-conservador deste autor, que vislumbrou a democracia como um dado imponderável do seu tempo. Tocqueville considerou que a democracia fundamentava-se na paixão popular pela igualdade e não na ampliação da liberdade, a qual, na verdade, a democracia bem poderia ameaçar. Deste modo, ele vai ser uma das grandes influências para os atuais ideólogos do "Terceiro Setor" e do neoliberalismo da Terceira Via, que concebem a necessidade de combater os supostos males da mobilização popular contra a desigualdade não pela repressão ou o cultivo da apatia política, mas justamente pela mobilização dos indivíduos em causas pontuais, locais e fragmentárias que não possam ameaçar o âmago do sistema capitalista.
\end{abstract}

Palavras-chave: Tocqueville; Associações livres; Democracia; Terceiro setor; Terceira via. 


\section{Abstract}

Based in the analyses of principal work of Alexis de Tocqueville, "Democracy in America", of 1830'years, it demonstrated the importance of free associations in liberal-conservative project of this thinker, what considerate the democracy as an imponderably element in his time. Tocqueville concepts that the democracy was not founded in freedom enlargement, but in popular passion from equality, so that, in truth, the democracy was a danger for the freedom. So, he is one of the great influences from the actual ideologists of "Third Sector" and neoliberals of Third Way, that concept the need of combat the socalled evils of popular mobilization against the inequality not by repression of the stimulus from political apathy, but just from the mobilization of individuals in little, local and fragmentary objectives that don't can menace the core of capitalist system.

Keywords: Tocqueville; Free associations; Democracy; Third sector; Third way.

\section{Introdução ${ }^{1}$}

O artigo inicia-se com a apresentação de Alexis de Tocqueville, político e pensador francês do século XIX, destacando sua obra "A democracia na América" e, de modo secundário, "Reflexões sobre a Revolução em França". Faz isto com o intento de demonstrar a importância das associações livres no projeto liberal-conservador deste aristocrata, que considerou a democracia como um dado imponderável dos novos tempos. Para tanto, discute-se aqui a concepção de que a democracia se fundamentaria na paixão popular pela igualdade e não na ampliação da liberdade, a qual, na verdade, a democracia bem poderia ameaçar.

Tocqueville vai abraçar, assim, o mito da "tirania da maioria", este que, oriundo ao menos dos pruridos antipopulares de Platão e Aristóteles, é renovado no moderno ambiente industrial e revolucionário da Europa Ocidental pelo autor de "A democracia na América". Esta é a segunda discussão deste

Agradeço ao Prof. Dr. Marcos Francisco Martins, do Programa de Mestrado em Educação do Unisal, pelos comentários e sugestões. 
artigo, que demonstra que, diferente de outros liberais-conservadores de outrora, e de muitos dos neoliberais de hoje, em Tocqueville a denúncia do suposto perigo das paixões populares pela igualdade não implica na defesa da repressão ou do cultivo da apatia política. $\mathrm{O}$ aristocrata propõe justamente o cultivo de pequenas liberdades e a descentralização político-administrativa, entre outras medidas supostamente bem-sucedidas nos Estados Unidos dos anos 1830, destacando, naquelas, o livre associativismo.

Nesse sentido, Tocqueville vai ser uma importante referência para os ideólogos contemporâneos do "neoliberalismo da Terceira Via" (NEVES, 2005), bem como para aqueles intelectuais orgânicos do "Terceiro Setor" de tom mais conservador (MONTAÑO, 2005). É a discussão da penúltima parte deste texto, que finda com a retomada de algumas das principais conclusões do artigo.

\section{O autor de "A democracia na América" e suas motivações}

Segundo Immanuel Wallerstein (2001), o século XIX construiu duas principais críticas ao capitalismo, ambas centradas na questão da igualdade e da desigualdade. Para alguns, o capitalismo trouxe ainda mais desigualdade social, focando, tal como Karl Marx e outros socialistas, as injustiças sociais e a exploração da classe trabalhadora. Trata-se de um olhar sobre os efeitos socioeconômicos do nascente industrialismo. Para outros, entretanto, o capitalismo teria trazido mais igualdade e, nesse sentido, ressalta-se o findar dos privilégios aristocráticos e a presença das massas na política. Trata-se de um olhar sobre os aspectos políticos e o sistema de atribuição de status na sociedade pós-tradicional. Entre os segundos, não foi exceção, bem ao contrário, a preocupação com os "excessos" da igualdade, denunciando-se o capitalismo como "[...] disruptivo da paz social e da harmonia comunitária" (WALLERSTEIN, 2001, p. 97).

Ainda em busca da interpretação das principais posições políticoideológicas do século XIX, é importante citar Maria Ribeiro do Valle (2005), que destaca a tradição hegeliano-marxista e a tradição liberal-conservadora na interpretação da violência popular revolucionária e da questão social. Enquanto é possível interpretar Hegel e, certamente, Marx como autores que admitem "[...] a necessidade da transformação social e da utilização da violência para tanto" (VALLE, 2005, p. 19), concepção retomada por Herbert Marcuse nos anos de 1960, a tradição liberal-conservadora - de Tocqueville a Hannah Arendt - condena " [...] a entrada das massas na Revolução Francesa, acusando-as de 
levar a violência para a política e de solapar os fundamentos da liberdade [...]", assim como enaltece a "[...] experiência americana por ter conseguido manter a questão social fora da esfera pública" (VALLE, 2005).

Provavelmente, o mais importante expoente do pensamento liberalconservador no século XIX, Alexis de Tocqueville (1805-1859), considerava a liberdade política como o valor maior a ser preservado, principalmente em meio aos perigos da nova sociedade "democrática". Deste modo, alinhava-se àqueles que criticavam o capitalismo, a nova sociedade moderna, por seu suposto excessivo igualitarismo sociopolítico oriundo do fim do Antigo Regime na Europa Ocidental. Enquanto que a liberdade era o grande valor a ser defendido, a igualdade era tão somente uma "paixão" social, fruto de instintos humanos que poderiam suscitar também inveja, rivalidade, egoísmo e agressividade -, uma tendência perigosa, uma caixa de Pandora aberta com o fim das hierarquias tradicionais, que precisava, de algum modo, ser contida.

Tocqueville era membro da antiga nobreza normanda, juiz do tribunal de Versalhes e político atuante. Chevallier (1999) chama-o de "homem superior", "aristocrata de nascimento" premiado com o dom da lucidez, amante da liberdade e da religião (que para ele se conciliavam) e capaz de usar sua sabedoria até mesmo contra seus próprios sentimentos de casta - o que o levou a ligar-se aos mais variados regimes, como a Restauração, o governo de Luís Felipe e a República, mesmo pessoalmente desprezando os dois últimos. Já Montaño (2005), citando Touchard, mostra um ardiloso Tocqueville que é capaz de conviver amigavelmente e fazer parte de governos de todos os poderosos da ocasião - mesmo em meio a tantas revoluções e mudanças bruscas de poder.

Em 1831, com Gustave de Beaumont, também juiz, desembarca nos EUA em missão requisitada por eles ao governo francês para estudar o sistema penitenciário norte-americano. Ficou lá apenas um ano. Na verdade, seu desejo era estudar as instituições sociais e políticas dos EUA, "que parecia ter resolvido com pleno êxito os problemas de liberdade e igualdade" (CHEVALLIER, 1999, p. 249), talvez com soluções a apontar para a conturbada França em constantes revoluções desde 1789.

A primeira parte da obra foi escrita entre 1832 e 1834, dedicada à "[...] influência da democracia nas instituições e costumes políticos dos americanos" (CHEVALLIER, 1999, p. 251). Publicada em 1835, teve imenso sucesso, tornando ilustre este nobre que ainda não completara 30 anos. Foi logo traduzida e publicada em várias línguas, com grande repercussão inclusive nos EUA. Paradoxalmente, direita e esquerda diziam que a obra dava-lhes razão: a direita, sobre os males da democracia; a esquerda, sobre a inexorabilidade desta. 
A segunda parte foi publicada em 1840, versando sobre a "influência da democracia nas idéias, sentimentos e costumes particulares dos americanos" (CHEVALLIER, 1999, p. 251). Esta custou mais tempo de trabalho, mas teve menos sucesso. É mais abstrata e generalizante.

Para diversos intérpretes, a obra fala, sobretudo, da "Democracia", mais que da "América". Nesse sentido, seu principal objetivo é a comparação dos EUA com a França. Talvez, a obra fale melhor - indiretamente - da França (segundo a interpretação de Tocqueville) que do próprio EUA. A França no tempo de Tocqueville é por ele vista como um país em estado de confusão, em que o sentimento de democracia e igualdade fora "abandonado" a seus "instintos selvagens". Pobres veriam os ricos com inveja; ricos veriam os pobres com terror. Estes sentimentos, inveja e terror, impediam a liberdade na nação francesa. Já os EUA seriam o país em que igualdade e liberdade puderam se conciliar em um processo (supostamente) pacífico. Estudar este país poderia trazer luz ao que se deveria fazer com a conturbada França.

Isso fica mais patente na segunda parte da obra, em que os capítulos iniciais, ao retomarem a primeira parte, falam em abstrato e em geral da democracia, não se referindo especificamente nem aos EUA e nem à França. Segundo Quirino (2001), tem-se uma espécie de construção “típico-ideal” (como que antecipando o famoso construto metodológico de Max Weber) de Democracia e de suas influências sobre as instituições e costumes.

\section{A democracia na América}

$\mathrm{Na}$ Introdução da obra, Tocqueville aponta que o fato gerador da história humana desde há muitos séculos, fazendo entrar em curso a "grande revolução democrática", é a "igualdade de condições". A revolução igualitária é tratada como um terrível desígnio divino, classificado como fruto da Providência Divina, portanto, universal, duradouro, contra o qual o homem nada pode fazer e para o qual ele age como um cego instrumento. Num primeiro momento, portanto, tem-se em Tocqueville uma sacralização e naturalização da história, que não é mais produto da ação dos homens e está fora de qualquer possibilidade de seu controle.

Ao mesmo tempo, o nobre francês considera que Deus dera aos homens o "livre-arbítrio", a liberdade, a capacidade de dirigir seus próprios destinos. Mas a classe capaz de exercer esta liberdade com mais perfeição e glória, a nobreza ou aristocracia, estava morta ou em desaparição. 
Nesse sentido, fazia-se cara a questão: como, a partir de então, conciliar a igualdade (desígnio divino para a humanidade) com a liberdade (qualidade humana cedida por Deus)?

A resposta é que seria possível constituir alguma liberdade no interior desta democracia que, aliás, poderia ser estendida a todo o povo, ainda que venha a ser uma liberdade menos "gloriosa" que aquela mais restritamente cultivada outrora na aristocracia. Mas para que isso fosse possível, era preciso regulamentar e canalizar pela lei este estado igualitário e fazer com que esta norma jurídica fosse respeitada e amada por todos, por meio do cumprimento dos direitos e deveres cívicos, da garantia da "liberdade interior" mediante a consciência religiosa e o cultivo da livre associação como defesa contra tendências despóticas do Estado.

Como que à espreita, há anunciado já acima um terceiro agente na história, que bem poderia ser o caminho natural da igualdade sem a intervenção deliberada humana: um novo Despotismo. Como se verá, ao descrever este novo despotismo, Tocqueville parece antecipar as características utilizadas por autores diversos do século XX para definir o Totalitarismo e a Massificação. Assim, estariam corretos, por exemplo, Montaño (2005) e Valle (2005) quando consideram que o maior temor de Tocqueville eram os processos revolucionários, o que o levava a preconizar que a inevitável igualdade/democracia não se deveria estabelecer via revolução, não afetando assim a "liberdade".

\section{Igualdade e liberdade}

Segundo Montaño (2005), a igualdade a que se referia Tocqueville não era tanto a igualdade econômica, mas sim a igualdade de condições ou oportunidades, principalmente a "cultural" e a "política". Ao descrever os males do desenvolvimento natural da democracia como igualdade de condições, principalmente o individualismo (maior inimigo, no campo dos costumes, da manutenção da liberdade), segundo Montaño, Tocqueville estaria mostrando "seu profundo repúdio pela igualdade e justiça social, como suposta ameaça à liberdade" (MONTAÑO, 2005, p. 67). Nesse sentido, mal se esconderia no aristocrata francês o temor de que a igualdade civil e política conquistada pelas revoluções populares fosse usada como arma contra a desigualdade socioeconômica tida como "natural" e imponderável. Ainda aqui, a igualdade em seus arroubos intempestivos estaria a ameaçar frontalmente o principal valor liberal-conservador: a "liberdade". 
Esta é fundamentalmente a liberdade política de discussão sobre o bem comum e a ação em prol deste bem. Interesses pessoais não poderiam influir nesta livre esfera de debates, em especial os desejos daqueles que buscariam na política dar cabo de suas necessidades de sobrevivência. Em boa parte, tem-se aqui um recurso ideológico de defesa de elites dirigentes supostamente capazes de ter a verdadeira dimensão sobre o bem comum, já que estariam livres daquela paixão que arrebata o homem medíocre por mais igualdade.

Mas isso não é tudo em Tocqueville. Ao contrário de parte importante dos liberais-conservadores de ontem e hoje, incluindo nos segundos os neoliberais stricto sensu, ele considerava necessário estimular a participação política dissuasiva do homem comum em pequenas ações locais para evitar a apatia política e paixões revolucionárias. Essa participação política em pequenas causas seria um excelente recurso para evitar a formação de agrupamentos de maior envergadura por parte das classes sociais subalternas - como o partido político operário e o sindicato, os quais agiriam de modo amplo, organizado e até com contundência em favor de um projeto alternativo de sociedade, em busca de uma igualdade também socioeconômica. ${ }^{2}$

Ao retomar os dois conjuntos de críticas elaboradas contra o capitalismo, segundo Wallerstein (2001), vê-se que Tocqueville pertence ao time dos conservadores, que apontam os males do igualitarismo. Mas olhando com mais calma, percebe-se que a posição de Tocqueville é resignada, já que, para ele, não era mais possível reverter o pretenso movimento de igualdade. $\mathrm{Da}$ crítica conservadora, também está presente o temor dos "males" da igualdade. Deixada a esmo, a igualdade iria desenvolver o que Tocqueville considera como suas "consequiências naturais" - todas elas, perniciosas e ardilosas: "Os males que a extrema igualdade pode produzir revelam-se lentamente; insinuam-se aos poucos na estrutura social, só são vistos a intervalos e no momento em que se tornam mais violentos, o hábito faz com que já não sejam sentidos" (TOCQUEVILLE, 1969, p. 221).

$\mathrm{O}$ aristocrata considera que a paixão mais poderosa no coração dos homens comuns, mais ainda que o amor à liberdade, era o amor à igualdade. Uma vez transposta alguma barreira social (ou seja, a superação dos privilégios tradicionais da nobreza), todas as outras barreiras sociais iriam cair rapidamente ou surgiriam demandas irresistíveis para que elas caíssem: "as nações

TOCQUEVILle, A. de. Democracia na América. São Paulo: Nacional, 1969. (Cap. 10, primeira parte) A crítica feita ao tipo de associações criadas pelas camadas populares na Europa que, ao contrário das solidárias da América, tendiam a ser "conspiratórias" e violentas. 
democráticas mostram um amor mais ardente e duradouro pela igualdade do que pela liberdade $[\mathrm{e}]$ a primeira paixão, e a mais intensa, produzida pela igualdade de condição é, nem preciso dizê-lo, o amor dessa igualdade" (TOCQUEVILLE, 1969, p. 219).

Essa paixão poderia levar os homens a substituir facilmente um governo livre pelo despotismo, caso o primeiro não garantisse ou não propiciasse mais igualdade. Certamente, diz Tocqueville, a igualdade social leva à igualdade política, mas este processo pode se dar por dois distintos meios: "o primeiro seria o aparecimento de uma sociedade de massa, permitindo que se realizasse uma Tirania da Maioria; o segundo seria o surgimento de um Estado autoritáriodespótico" (QUIRINO, 2001, p. 168).

No primeiro caso, o da soberania de todos, está os EUA. Lá supostamente haveria o poder absoluto da maioria, que comanda a opinião pública, o Poder Legislativo, Executivo e a força pública. Contudo, esta contém em si o perigo da Tirania da Maioria.

É que a verdadeira fonte desta soberania de todos seria o individualismo. Cada indivíduo passa a buscar em si mesmo suas idéias, opiniões e crenças, apelando para sua razão individual, não mais para a tradição ou aos "homens superiores de sua época". Gera-se na prática o método de livre exame individual de todas as crenças. Mas esta prática disseminada pode gerar, no limite, algo que parece ser o seu avesso: o desejo do homem igualitário ter a mesma opinião de seus semelhantes, pressupondo uma espécie de crença na "infalibilidade das massas". Já que, com a igualdade, todos se tornam semelhantes, a liberdade passa a se limitar na prática pelas opiniões da maioria. O próprio movimento de libertação intelectual do indivíduo gera sua extinção na prisão da opinião da maioria (dir-se-ia depois que se trata do processo de massificação):

Passeio meu olhar sobre essa multidão inumerável, composta de seres parecidos, onde nada se eleva nem se abaixa. O espetáculo dessa uniformidade universal me entristece e me gela, e sou tentado a ter saudades da sociedade que não mais existe. Quando o mundo era cheio de homens muito grandes e muito pequenos, muito ricos e muito pobres, muito sábios e muito ignorantes, eu afastava meus olhos dos segundos para não os prender senão nos primeiros, e isto me alegrava a vista (TOCQUEVILLE, 1969, p. 362-3).

O individualismo também produz o isolamento, a tendência de o indivíduo se isolar com sua família em relação aos demais em seu tempo e aos 
seus antepassados. Isso acarreta o fechamento do indivíduo em ocupações mesquinhas da vida particular, a mediocridade, que leva ao esvaziamento do sentido de civismo, cidadania e envolvimento com a vida pública.

Tirania da maioria, massificação, isolamento e mediocridade estariam levando nações como a França para o outro caminho da danação, o despotismo, via a crescente centralização administrativa no e do Estado. Os homens democráticos são levados a ele por suas idéias, sentimentos e outras causas particulares, como se descreve a seguir.

No campo das idéias, rompe-se a crença de que existem corpos intermediários ou corporações secundárias entre o Estado e os indivíduos, substituída pela crença de que deve haver um poder único e central, "que, sozinho, toma a si o encargo de garantir a satisfação de seus desejos (dos homens comuns) e de prestar vigilância sobre seu destino" (TOCQUEVILLE, 1969, p. 347). É que a democracia apreciaria sempre mais as idéias simples e gerais, como o Estado centralizador, assim como a legislação uniforme. Quase que num instante, vê-se Tocqueville considerar a igualdade perante a lei e ao poder público como meras idéias medíocres do homem da multidão, e não conquistas fundamentais das revoluções contra o Antigo Regime.

No campo do sentimento, o fato de o homem individual sentir-se débil ao se isolar, ao lado do ódio ao privilégio, o faz desejar um poder incontestável como o de um Estado superior e centralizado.

Entre as causas particulares e acidentais, estão as guerras - que aumentam as atribuições do Estado -, as revoluções - que costumam suprimir bruscamente os corpos e poderes intermediários entre indivíduos e Estado - e o desenvolvimento da indústria - que cria novas classes, patrões e operários, em cujas relações o Estado é obrigado a intervir como regulamentador (e, na verdade, o próprio Estado torna-se industrial/patrão). Passo a passo, caridade, educação e mesmo assuntos religiosos tornam-se instituições e/ou assuntos do Estado.

Este tema do caminho que leva ao despotismo, via centralização administrativa, será também discutido na obra inacabada de Tocqueville, $O$ Antigo Regime e a Revolução, na qual a centralização do Estado francês se dá como decorrência de um lento processo de dissolução das instituições feudais pelo absolutismo, concluído subitamente pela Revolução Francesa. O Antigo Regime já criara um Estado centralizado, cujas regulamentações e administração vigoravam em todo o país, do qual os corpos administrativos secundários tinham dependência. O que a Revolução fez foi simplesmente "derrubar tudo o que existia a seu redor (deste Estado centralizado) ou retirar-lhe nada de essencial" (TOCQUEVILLE, 1973, p. 343). 
Quanto ao novo despotismo, ele seria diferente daquele despotismo a que decaiu a civilização romana antiga. Não é um despotismo pesado e violento, ainda que restrito, de tiranos. Haveria de ser um despotismo suave que degradaria os homens sem violência, de tutores que cuidariam e interferiram nos mínimos detalhes da vida dos indivíduos uniformes e isolados (TOCQUEVILLE, 1969, cáp. 56, segunda parte). Alguns veriam em diversos regimes do século XX, como o fascismo e o comunismo soviético, este despotismo na forma do totalitarismo, ainda que soubessem enxergar neste um uso bem maior da violência que aquela um dia profetizada por Tocqueville.

De todo modo, voltando ao século XIX e Tocqueville, o político e pensador francês considerava que os norte-americanos conseguiram desenvolver diversos remédios contra os perigos do novo despotismo. Em suma, o remédio contra o individualismo nascido da igualdade é a liberdade. Só a liberdade política poderia tornar proveitosa à humanidade a igualdade social, e não a tentativa de recriar a sociedade aristocrática, como, em vão, a Restauração tentou fazer na França. Tocqueville considera que não seria eficiente o governo misto (proposta de Montesquieu), pois logo se descobriria que o verdadeiro princípio da vida política, na modernidade, era mesmo a soberania popular.

Contra o risco de perder-se a liberdade, era necessário que instituições políticas “obrigassem" os indivíduos a sair de si mesmos e tirar-lhe da apatia. Entre estas instituições, as liberdades locais, as associações e a religião.

Como liberdades locais, Tocqueville considera as instituições provinciais e municipais que produzem uma "descentralização" administrativa (TOCQUEVILLE, 1969, cap. 3-4, primeira parte). Por meio destas, os indivíduos são levados a participar de modo efetivo nas questões políticas e públicas de sua localidade - o que é muito mais possível e efetivo do que participar das grandes e gerais questões da nação (as quais podem ser deixadas a cargo das elites dirigentes "naturais") - e se obrigam ao auxílio mútuo. Conformam uma espécie de novos corpos intermediários entre Estado e indivíduos, substituindo as antigas corporações.

Quanto à religião, é onipresente o desejo de Tocqueville conciliar a paixão pela liberdade e o cristianismo. Seria algo que ele constatara nos EUA e que se dera, na verdade, desde a fundação da Nova Inglaterra pelos puritanos (TOCQUEVILLE, 1969, cap. 1, primeira parte). Entre as funções da religião, estava a de assegurar os costumes (ou como diria o sociólogo Émile Durkheim (1947), moderar os desejos), o que protege a liberdade e promove a higiene interior de cada cidadão e o fortalecimento do vínculo político através do vínculo moral pela fé. Para ele, a moderação dos desejos e a estabilidade promovida pela religião 
são um necessário contraponto ao eterno movimento e agitação da democracia, garantindo assim a liberdade: "A preocupação principal da religião é purificar, regular e restringir o gosto excessivo e exclusivo pelo bem-estar que o homem sente em períodos de igualdade" (TOCQUEVILLE, 1969, p. 179).

Enfim, um dos temas que mais fazem Tocqueville ser utilizado como teórico do contemporâneo "Terceiro Setor": as associações livres:

Em país algum do mundo se utilizou com tamanho sucesso o princípio da associação, e se aplicou o mesmo a maior número de objetivos, quanto na América. Além das associações permanentes, estabelecidas por lei, sob os nomes de distritos, cidades, municípios e condados, forma-se e mantém-se um vasto número de outras por iniciativa de indivíduos privados. (TOCQUEVILLE, 1969, p. 112).

Havia, então, nos EUA, associações em número enorme e com uma impressionante gama de objetivos, tais como: crianças auto-regulamentando seus jogos na escola, pedestres formando assembléia com vizinhos e resolvendo questão em acidente de trânsito, organização de festas, seminários, construção de obras públicas, difusão de livros e envio de missionários, promoção da segurança pública, comércio, indústria, moralidade e religião, etc. Segundo Tocqueville, os cidadãos preferem fazer isso eles próprios em vez de esperar que o governo o faça - cuja ação costuma ser insuficiente e perigosa por atentar contra a liberdade, já que acostumaria os indivíduos à apatia e sujeição. Tocqueville compara a força do exemplo de inúmeros indivíduos associados em uma sociedade democrática ao bom exemplo de um aristocrata em uma sociedade tradicional. Este comportamento, de procurar resolver as questões cotidianas por si mesmo, em vez de esperar ou mesmo clamar ao Estado para que as resolva, não apenas promoveria a descentralização administrativa, como promoveria "a defesa de direitos e interesses particulares comuns dos cidadãos associados" (MONTAÑO, 2005, p. 68).

Por meio destes recursos, em destaque as associações livres, "os americanos combateram [...] a tendência da igualdade a manter os homens separados e venceram" (TOCQUEVILLE, 1969, p. 226). E o espírito do interesse pelo bem comum se garantiu pelo estímulo à formação e reconhecimento destas associações:

É difícil tirar um homem de seu próprio círculo para interessá-lo no destino do Estado, porque ele não compreende claramente que o destino do Estado possa ter na sua sorte. Mas se for proposta a 
construção de uma estrada que atravesse o extremo de sua propriedade, ele $\operatorname{logo}$ vê a ligação entre esse pequeno negócio público e seus maiores negócios privados; e descobrirá, sem que isso lhe seja demonstrado, o elo íntimo que une o interesse privado ao geral. Assim, muito mais se pode fazer confiando aos cidadãos a administração dos pequenos negócios do que entregando-lhes o controle dos importantes para fazer com que se interessem pelo progresso social público. (TOCQUEVILLE, 1969, p. 227).

\section{A "tirania da maioria"}

Tocqueville não foi o primeiro, muito menos o último, a ver na democracia, sobretudo, o perigo da "tirania da maioria". Já na Antigüidade, Aristóteles considerava a democracia como um tipo degradado de sistema político, em que o governo da maioria é feito pelo interesse da maioria (DAHL, 1970). Ele e outros vários pensadores políticos aristocráticos da Antigüidade afirmaram não apenas o caráter pernicioso da democracia, como também que ela antecede a tirania - quando um tirano diz-se representar os desejos e interesses do "povo" e tem a ele atribuído todos os poderes.

Outro destes é um "iluminista", que, assim como Tocqueville, era um aristocrata francês moderado, o Barão de Montesquieu, cuja obra $O$ Espírito das Leis tem muito do estilo que Tocqueville utilizou depois (MONTESQUIEU, 1937). Mas o regime político predileto de Montesquieu é a Monarquia Constitucional, cujo modelo era o governo inglês, um governo misto capaz de garantir certo grau de liberdade e estabilidade.

Reacionários como o inglês Edmund Burke, feroz crítico da Revolução Francesa, diferentemente de Tocqueville, viam a democracia e o processo de igualdade como perversão da história, que em breve haveriam de gerar o castigo divino como justo resultado (BURKE, 1982).

Os Federalistas, pensadores e políticos ${ }^{3}$ muito importantes no processo de criação do novo Estado norte-americano e sua Constituição, teriam preconizado uma série de "remédios" na sua Lei Magna e na democracia americana para evitar o que seria para eles o maior perigo da vida política, a Tirania da Maioria. Uma série de mecanismos do sistema eleitoral - como mais representatividade para estados menores (tanto no Senado quanto na Câmera

Entre os quais se destacam Alexander Hamilton, James Madison e John Jay. 
de Representantes), eleição indireta para presidente, artigos constitucionais praticamente invioláveis (para garantia de propriedade e autodefesa) etc. serviriam para garantir o chamado "Direito das Minorias" (MADISON; HAMILTON; JAY, 1979). Na verdade, os Federalistas pareciam preocupados sobretudo com a defesa de camadas aristocráticas e burguesas que poderiam ter seus privilégios e propriedades ameaçados pelo princípio da soberania popular.

Como já foi dito, Tocqueville teria seus precursores e seguidores, no século XIX, na denúncia contra a Tirania da Maioria. Grande parte dos liberais políticos do século XIX está, tal qual o nobre francês, menos preocupada com Estado Absolutista e mais com os "perigos" da Revolução e da idéia de soberania popular, ou seja, o aprofundamento da democracia. Até mesmo Stuart Mill, mas principalmente pensadores como Benjamin Constant (antes de Tocqueville) e Herbert Spencer (depois) (MILL, 1963; SPENCER, 1977).

O liberal-conservadorismo de Tocqueville parece presente até em Émile Durkheim, sociólogo francês da virada do século XIX ao XX. Outros sociólogos do século XX, como Raymond Aron deixaram explícita sua admiração por Tocqueville (ARON, 2002). As teses da rebelião da multidão, da massificação e do totalitarismo têm em Tocqueville um importante precursor, não apenas em conservadores da virada do século XIX ao XX, como Ortega y Gasset, com seu livro “A Rebelião das Massas" (ORTEGA Y GASSET, 2002), mas até mesmo na retomada "progressista" da denúncia da massificação pela Escola de Frankfurt ${ }^{4}$ e na tese da "Multidão Solitária" do norte-americano David Riesman (1971). Há, enfim, no pensamento progressista, a adoção das teses do Totalitarismo por liberais radicais e democratas como Hannah Arendt (VALLE, 2005) e Claude Leforte (1987), entre outros críticos dos regimes fascistas e comunistas.

É possível dizer também que Tocqueville traduziu um forte movimento de associativismo na sociedade norte-americana, que se manteve no século passado e mesmo hoje em dia. Mas enfatizou menos o fato de os EUA terem milhares de experiências com comunidades de tipo utópico inspiradas em Robert Owen, Jacques Fouerier, anarquistas e outros (WILSON, 1986), e mais as associações de interesse e fundações. Fundações e outras

\footnotetext{
4 Sobre a semelhança da desconfiança nas "massas" entre autores conservadores (como Ortega y Gasset) e autores da Escola de Frankfurt (como Theodor Adorno), afirma Ortiz (ORTIZ, R. Ciências sociais e trabalho intelectual. São Paulo: Olho d'Água, 2002. p. 37): "Mesmo tomando-se todas as precauções possíveis, seria difícil escapar a uma comparação. A desconfiança com que os frankfurtianos vêem a massa encontra certamente um antecedente neste tipo de literatura".
} 
organizações filantrópicas com muita ligação com o Estado iriam participar de "missões" de desenvolvimento no século XX, como aquelas apoiadas pela própria ONU (Organização das Nações Unidas) e que lançaram a moda do "Desenvolvimento de Comunidade" (AMMANN, 2003) - sob princípios muito parecidos com aqueles abaixo discutidos.

\section{Tocqueville e a defesa do terceiro setor}

Muitos pensadores do Terceiro Setor deixam mais ou menos explícita a sua filiação a Tocqueville ou ao tipo de tradição liberal-conservadora que ele representa. Carlos Montaño, sobre esta influência do autor de "A democracia na América", faz várias considerações muito importantes (MONTAÑO, 2005, p. 69-76).

A primeira inspiração de Tocqueville é o seu temor da revolução e a ojeriza às massas, mas com a aceitação resignada (nunca apaixonada) da democracia. Projeta-se um paradoxal desejo de manter a liberdade na desigualdade, a qual é "composta de microigualdades". Busca-se afastar os perigos da igualdade fazendo-a funcionar no "nível desarticulado das associações livres na sociedade civil" (MONTAÑO, 2005, p. 70).

Segundo, Tocqueville preconizaria uma democracia apenas formal, de participação limitada popular, em geral apenas no "silencioso ato eleitoral". Seu diferencial, contudo, está no fato de defender tal participação limitada também no nível das associações livres e dos governos locais - ainda, acima de tudo, com o objetivo de preservar a liberdade formal favorável às classes dominantes.

Nesse sentido, já que o povo não teria capacidade de atuar nos "grandes negócios do Estado", na grande política, deveria se permitir que, de algum modo, participasse fora dele, na "sociedade civil". Se a igualdade plena não deve (mais do que não pode) ser alcançada, deve se dar a "igualdade pontual entre associados" no âmbito apenas da sociedade civil, e não no mundo político. Trata-se de uma espécie de pacto social entre as classes: a minoria realmente dominante e dirigente estimula a maioria para associar-se livremente segundo interesses particulares compartilhados. Nesse sentido, democracia apenas formal e associativismo são males menores, que permitem que a minoria continue tendo o poder real e de fato, no qual a participação popular é uma participação subordinada.

As associações livres são concebidas segundo o modelo tradicional das corporações, ou seja, como "associações representativas dos interesses e 
das atividades segundo ramos profissionais" (MONTAÑO, 2005, p. 73), portanto, como agrupamentos extra ou interclasses, nunca por ligações classistas, mas por recortes profissionais, congregando juntos até mesmo patrões e empregados - o que hoje tentam fazer as Fundações Empresariais. Ou então, por bairro, gênero, idade, religião, opinião política, causa privada, etc. Trata-se de um modelo baseado na "colaboração entre as classes", uma alternativa mesmo ao modelo de organização sindical e à democracia participativa.

Assim, a participação popular nas associações é vista como um antídoto às lutas classistas em busca de igualdade e liberdade mais substanciais pelas classes trabalhadoras. Trata-se de uma forma "tranqüila e racional de convivência (pacífica) com a autoridade instituída no Estado" (MONTAÑO, 2005, p. 75). Não se trata de ampliação do poder popular. O modelo de Tocqueville era o capitalismo liberal norte-americano, não a ideologia do socialismo. Que insubordinação, tirania e maioria realmente Tocqueville e outros poderosos de então tinham tanto temor? Trata-se dos trabalhadores lutando contra os privilégios das elites, fazendo uso das possibilidades dos modernos sistemas políticos democráticos para ampliar sua luta pela igualdade substancial. Talvez ainda mais que uma aceitação resignada da democracia, a herança de Tocqueville é um projeto conservador e regressivo que é capaz de chamar à participação as camadas populares, mas por causas pontuais, fragmentadas e distantes de qualquer contestação ao coração do sistema socioeconômico imperante.

Ao contrário do conservadorismo do século XIX e do liberalconservadorismo de Herbert Spencer, a combinação entre a liberdade como valor-mor com a preocupação de assegurar a "ordem social" não fez de Tocqueville um defensor da apatia política popular, como acima discutido. $\mathrm{O}$ mesmo se pode dizer, hoje, a respeito do renovado neoliberalismo em versão "Terceira Via" em comparação com o neoliberalismo stricto sensu.

As soluções contra o perigo desta emergência de um novo despotismo ou totalitarismo apregoadas por Tocqueville ficaram um tanto quanto eclipsadas durante certo tempo, inclusive durante o período da hegemonia ideológica do neoliberalismo stricto sensu, no final do século passado. Este neoliberalismo, a par do dogma da infalibilidade do mercado, pregava a necessidade do Estado policial e do cultivo da apatia política para que as demandas populares não ganhassem expressão pública e não levassem governos a intervir no livre fluxo da economia de mercado (MORAES, 1996).

Mas as teses e os remédios contra o perigo da tirania da maioria e do novo despotismo, do aristocrata francês, parecem ter finalmente retornado com vigor hoje, reverberando nas propostas da Terceira Via e do Terceiro Setor. 
Destacam-se, entre estas propostas, a defesa do associativismo, do voluntariado, da participação do cidadão em pequenas questões coletivas e a descentralização do poder político. Atualmente, assistimos à pregação e implementação de medidas que parecem retomar o legado de Tocqueville, divulgadas por instituições políticas e econômicas supranacionais e de governos nacionais a elas submissos. Entre estas medidas, a regionalização, municipalização e repasse de atribuições a associações ou organismos da "sociedade civil", em especial daquilo que se refere a serviços sociais, incluindo a educação, a saúde e a assistência. Medidas usadas hoje também, ou principalmente, com a finalidade de completar o desmanche de Estados socialmente atuantes (cujo modelo-mor foi o Estado de Bem-Estar europeu) e a transformação dos serviços sociais, de direitos universalmente reconhecidos, em benefícios mantidos "caridosamente" por associações e governos locais. ${ }^{5}$

Ainda entre estas medidas, o da legitimação de uma certa noção de "sociedade civil ativa", concebida como um conjunto de múltiplas associações voluntárias focadas em questões micro e locais, tirando o indivíduo da apatia, mas também o desmobilizando de possíveis paixões ferozes contra a desigualdade econômica que estariam sempre à espreita para alimentar revoluções. Aquelas revoluções populares, cujos resultados, conforme apregoados provavelmente já desde bem antes de Tocqueville, somente trariam o caos, a fratura social, a desconfiança entre as classes sociais e o aumento do poderio do Estado central.

De todo modo, uma motivação presente em Tocqueville que continua nas perspectivas liberal-conservadoras contemporâneas, incluindo aí o neoliberalismo stricto sensu bem como o neoliberalismo da "Terceira Via", é a preocupação em conter o desejo popular pela igualdade. Traduz-se e renova-se um temor e um mito das classes dominantes: a "tirania da maioria". Em Tocqueville, delineia-se mesmo um processo típico-ideal que explica a emergência desta tirania e sua metamorfose numa forma nova de despotismo - que no século XX foi nomeada por diversos pensadores políticos como "totalitarismo": sua origem na suposta apatia política do homem comum e no individualismo.

Para o neoliberalismo da Terceira Via, recuperando ao menos em parte o ideário de Tocqueville, não se deve inibir a participação política - exceto aquela que contesta o âmago do sistema capitalista - nem valorizar a apatia política,

Para uma versão da Terceira Via, cf. GIDDENS, A. A terceira via: reflexões sobre o impasse político atual e o futuro da social-democracia. 4. ed. Rio de Janeiro: Record, 2001. Para uma demonstração das relações entre Terceira Via e neoliberalismo, cf. LIMA, K. R. S. L.; MARTINS, A. S. Pressupostos, princípios e estratégias. In: NEVES, L. M. W. (Org.). A nova pedagogia da hegemonia: estratégias do capital para educar o consenso. São Paulo: Xamã, 2005. p. 43-67. 
nem mesmo renegar a atuação social do Estado mesmo como simples gestor de políticas sociais a se realizar por intermédio de organizações da sociedade civil. Ainda que o sistema capitalista não seja, mesmo em sua face global e neoliberal, sequer arranhada pelo que preconiza a Terceira Via, concebem-se remédios contra resultados socioeconômicos por demais perniciosos oriundos da aplicação rigorosa do neoliberalismo stricto sensu. Mas não se trata de recorrer aos mecanismos do Estado de Bem-Estar, bem ao contrário, busca-se justamente se prevenir contra a necessidade de ter que adotar mecanismos que efetivamente façam a redistribuição de riquezas e concebam os serviços sociais como direitos. Nesse sentido, erige-se o projeto de um Estado gestor de ações sociais, o qual formula os contornos gerais das políticas sociais e até as financia, mas que devem se realizar pela mobilização de cidadãos voluntários ou pretensamente voluntários, por meio de associações livres ou pretensamente livres, para a atuação em questões em escala local e fragmentadas. (MELO; FALLEIROS, 2005).

Há, deste modo, uma nova politização ou uma repolitização, como definem os autores reunidos em torno da bela obra de Neves (2005). Nesta repolitização da sociedade, os cidadãos tornam-se voluntários em associações em destaque, as Organizações Não-governamentais profissionalizadas e Fundações empresariais. Evita-se o risco de qualquer mobilização mais conseqüente das insatisfações sociais em prol de transformações estruturais, mediante a sublimação das energias ativas e dos desejos humanos latentes em projetos focalizados que, direta ou indiretamente, contribuem, à deriva da consciência destes voluntários, para a implementação do projeto hegemônico de sociedade hoje vigente.

\section{Conclusão}

Recentemente, a multiplicação do "voluntariado" - definido como o dispor de um pouco de tempo de si para ser "solidário" com o outro, em especial por meio do engajamento em Organizações Não-Governamentais e projetos de Responsabilidade Social propalados por Fundações Empresariais - vem sendo considerada como a ponta de lança da erupção de uma nova "sociedade civil" ativa. Anthony Giddens (2001), um dos pais da "Terceira Via", doutrina que tão bem legitima a noção vigente do "Terceiro Setor", ${ }^{6}$ vem, para tanto, fazer uso de sua sofisticada tese sobre a reflexividade das

6 MONTAÑO, C. Terceiro setor e a questão social: crítica ao padrão emergente de intervenção social. 3. ed. São Paulo: Cortez, 2005. p. 49-87. 
sociedades pós-tradicionais (GIDDENS, 1997) para tentar referendar esta valorização. Com a expansão da reflexividade, necessário cultivo do saber, da flexibilidade e mobilidade pelos indivíduos contemporâneos, eles seriam mais capazes de controlar suas atividades e os significados delas, o que erige a possibilidade e a necessidade de se criar uma "sociedade civil ativa" em que os indivíduos associados atuam menos na "cômoda" posição de reivindicadores de direitos, e mais como sujeitos atuantes na "prestação de serviços" (LIMA; MARTINS, 2005, p. 50).

Não seria forçado dizer que Giddens reatualiza, neste ponto, as teses de Alexis de Tocqueville sobre o necessário engajamento dos indivíduos em associações ativas em pequenas causas e na solução de problemas pontuais do cotidiano. Há, é claro, diferenças muito importantes, já que em Giddens têm-se indivíduos mais inteligentes, portanto capazes de mobilizar-se eficazmente na resolução autônoma de questões do dia-a-dia de sua comunidade, contribuindo, assim, com a "governança" e a concertação social promovidos pelo novo Estado da Terceira Via; enquanto que em Tocqueville têm-se homens medianos, medíocres e semelhantes entre si na sua pouca inteligência, felizmente mobilizados - no caso dos Estados Unidos -, graças à leveza do processo de democratização da América, na participação em governos locais e associações voluntárias, o que se torna um remédio contra a perda da liberdade e uma barreira contra as revoluções violentas.

De qualquer forma, renovam-se mitos e devaneios das elites políticas e econômicas da civilização moderna: o avanço do capitalismo como a promoção da igualdade substancial; a democracia como decorrência "natural" (ou divina) dos processos históricos - e não como fruto das lutas populares; os perigos contidos na paixão popular pela igualdade, em especial o seu atentado contra a "liberdade" (não a liberdade de todos, mas sim a dos homens magnânimos das elites de ontem e de hoje); o mito da "tirania da maioria"; e a premonição do totalitarismo como um castigo pela apatia dos medíocres homens-massa.

Assim, não é à toa que Alexis de Tocqueville vem sendo convocado, de modo assumido ou disfarçado, pelos liberal-conservadores do presente, para re-sistematizar estes medos e mistificações em teoria política, bem como para inspirar a proposição de medidas destinadas a conter aquilo que supostamente compõe os extremos indesejados do comportamento político do homem comum, a apatia e a revolução violenta. Entre as medidas, a livre associação destes homens comuns na busca de pequenos benefícios para si, podendo, assim, compreender a importância de participar do engajamento dito "propositivo" na esfera pública, naquela porção pequena da política que suas mentes podem alcançar e suas ações influenciar. 


\section{Referências}

AMMANN, S. B. Ideologia do desenvolvimento de comunidade no Brasil. 10. ed. São Paulo: Cortez, 2003.

ARON, R. As etapas do pensamento sociológico. São Paulo: Martins Fontes, 2002.

BURKE, E. Reflexões sobre a Revolução em França. Brasília: Universidade de Brasília, 1982.

CHEVALLIER, J-J. As grandes obras políticas: de Maquiavel a nossos dias. 8. ed. Rio de Janeiro: Agir, 1999.

DAHL, R. A. A moderna análise política. Rio de Janeiro: Libador, 1970.

DURKHEIM, É. La Educación moral. Buenos Aires: Losada, 1947.

GIDDENS, A. A vida em uma sociedade pós-tradicional. In: BECK, U.; GIDDENS, A.; LASH, S. Modernização reflexive: política, tradição e estética na ordem social moderna. São Paulo: Editora da Unesp, 1997. cap. 2, p. 73-134.

A terceira via: reflexões sobre o impasse político atual e o futuro da social-democracia. 4. ed. Rio de Janeiro: Record, 2001.

LIMA, K. R. S. L.; MARTINS, A. S. Pressupostos, princípios e estratégias. In: NEVES, L. M. W. (Org.). A nova pedagogia da hegemonia: estratégias do capital para educar o consenso. São Paulo: Xamã, 2005. p. 43-67.

LEFORT, C. A invenção democrática: os limites da dominação totalitária. São Paulo: Brasiliense, 1987.

MADISON, J.; HAMILTON, A.; JAY, J. O federalista. São Paulo: Abril, 1979. v. 29. (Coleção Os Pensadores).

MELLO, M. P. de; FALLEIROS, I. Reforma da aparelhagem estatal: novas estratégias de legitimação social. In: NEVES, L. M. W. (Org.). A nova pedagogia da hegemonia: estratégias do capital para educar o consenso. São Paulo: Xamã, 2005. p. 175-192.

MILL, J. S. Da liberdade. São Paulo: Ibrasa, 1963.

MONTAÑO, C. Terceiro setor e a questão social: crítica ao padrão emergente de intervenção social. 3. ed. São Paulo: Cortez, 2005. p. 49-87. 
MONTESQUIEU, C. S. B. de. O espírito das leis. São Paulo: Cultrix, 1937.

MORAES, R. C. C. de. A democracia malcomportada. A teoria política do neoliberalismo econômico. Universidade e Sociedade, São Paulo, ano 6, n. 11, p. 121-129, jun. 1996.

NEVES, L. M. W. (Org.). A nova pedagogia da hegemonia: estratégias do capital para educar o consenso. São Paulo: Xamã, 2005.

ORTEGA Y GASSET, J. Rebelião das massas. São Paulo: Martins Fontes, 2002.

ORTIZ, R. Ciências sociais e trabalho intelectual. São Paulo: Olho d'Água, 2002.

QUIRINO, C. G. Tocqueville: sobre a liberdade e a igualdade. In: WEFFORT, F. C. (Org.). Os clássicos da política 2. 10. ed. São Paulo: Ática, 2001. p. 149-160.

RIESMAN, D. A multidão solitária: um estudo da mudança do caráter americano. São Paulo: Perspectiva, 1971.

SPENCER, H. El individuo contra el Estado. Madrid: Jucar, 1977.

TOCQUEVILLE, A. de. Democracia na América. São Paulo: Nacional, 1969.

O antigo regime e a revolução. São Paulo: Abril Cultural, 1973. v. 29. (Coleção Os Pensadores).

VALLE, M. R. do. A violência revolucionária em Hannah Arendt e Herbert Marcuse: raízes e polarizações. São Paulo: Unesp, 2005.

WALLERSTEIN, I. Capitalismo histórico e civilização capitalista. Rio de Janeiro: Contraponto, 2001.

WILSON, E. Rumo à estação Finlândia. São Paulo: Cia. das Letras, 1986. 